\title{
Korelasi Kadar Prokalsitonin dan Jumlah Eosinofil pada Pasien Sepsis di Ruang Intensive Care Unit RSUD Dr. Saiful Anwar, Malang
}

\author{
The Correlation Between Procalcitonin and Eosinophils in Sepsis Patients \\ at Intensive Care Unit of Dr. Saiful Anwar General Hospital, Malang
}

\author{
Ruddi Hartono $^{\bowtie}$, Karmini Yupono, Yana Agung Satriasa, Arie Zainul Fatoni \\ Departemen Anestesiologi dan Terapi Intensif, Fakultas Kedokteran, Universitas Brawijaya/ \\ RSUD Dr. Saiful Anwar, Malang, Indonesia
}

${ }^{\circledR}$ Korespondensi: hartonoruddi@ub.ac.id

\section{ABSTRACT}

Background: Sepsis caused by the unbalance body defense against infection and potentially cause a fatal complication. Procalcitonin is the latest and the most accurate biomarker found in the clinical diagnosis of sepsis and is the most accurate parameter. Eosinopenia is known as an acute inflammatory response and can be used as a sepsis diagnosis biomarker.

Objective: The purpose of this study was to determine the correlation between procalcitonin levels and the number of eosinophils in sepsis patients.

Methods: This study was an analytic observational descriptive study on 74 sepsis patients. The data found from the medical data record of Dr. Saiful Anwar General Hospital. The data were analyzed using the Spearman correlation test $(p<0.05)$ using SPSS 16 software.

Result: There was a strong correlation between procalcitonin levels and eosinophil numbers $(p=0.000)$ with a correlation coefficient of -0.610. The procalcitonin level shows a negative correlation to the number of eosinophils.

Conclusion: Eosinophils are proven to have a strong correlation with procalcitonin. Eosinophils potentially can be an alternative biomarker of sepsis diagnosis in the hospital that does not have procalcitonin level examination facilities.

Keywords: eosinophil; intensive care unit; procalcitonin; sepsis; sepsis biomarker

\begin{abstract}
ABSTRAK
Latar Belakang: Sepsis merupakan suatu kondisi di mana terjadi ketidak seimbangan sistem pertahanan tubuh ketika terjadi infeksi. Prokalsitonin merupakan parameter baru yang berperan penting dalam diagnosis klinis sepsis dan merupakan parameter yang paling akurat. Eosinopenia diketahui sebagai respons inflamasi tipe akut sehingga dapat digunakan sebagai salah satu penanda diagnosis sepsis.
\end{abstract}


Tujuan: Tujuan penelitian ini adalah mengetahui hubungan antara kadar prokalsitonin dengan jumlah eosinofil pada pasien sepsis.

Metode: Penelitian ini merupakan penelitian deskriptif observasional analitik untuk mengkaji hubungan antara prokalsitonin dengan jumlah eosinofil pada pasien sepsis yang dirawat di intensive care unit (ICU) RSUD Dr. Saiful Anwar Malang. Penelitian ini menggunakan data rekam medis 74 pasien sepsis yang diperiksa kadar prokalsitonin dan jumlah eosinofil. Data yang diperoleh dianalisis dengan uji korelasi Spearman $(\mathrm{p}<0.05)$ menggunakan software SPSS 16.

Hasil: Hasil penelitian menunjukkan jika ada korelasi yang kuat antara kadar prokalsitonin dan jumlah eosinofil $(\mathrm{p}=0.000)$ dengan koefisien korelasi -0.610 . Penderita sepsis memiliki kadar prokalsitonin yang berbanding terbalik dengan jumlah eosinofil.

Kesimpulan: Eosinofil dibuktikan memiliki korelasi yang kuat dengan prokalsitonin. Eosinofil berpotensi menjadi alternatif biomarker diagnosis sepsis pada fasilitas kesehatan yang tidak memiliki fasilitas pemeriksaan kadar prokalsitonin.

Kata Kunci: biomarker sepsis; eosinofil; intensive care unit; prokalsitonin; sepsis

\section{PENDAHULUAN}

Sepsis merupakan salah satu masalah kesehatan global. Sebanyak 13 juta orang di dunia mengalami sepsis dan 4 juta diantaranya meninggal dunia. Jumlah pasien yang dirawat di intensive care unit (ICU) juga terus meningkat. ${ }^{1}$ Penelitian yang telah dilaksanakan di RSUD Dr. Soetomo Surabaya menjelaskan jika 504 dari 4.774 pasien yang dirawat didiagnosa sepsis dengan tingkat mortalitas sebesar $70.2 \%$. $^{2}$

Berbagai penanda diagnosis sepsis telah dikembangkan untuk membantu diagnosis. ${ }^{3}$ Penanda diagnosis sepsis yang ideal harus memiliki spesifikasi dan sensitivitas tinggi, cepat, mudah dan berkorelasi dengan derajat keparahan dan prognosis. Penelitian menunjukkan bahwa pemantauan konsentrasi plasma prokalsitonin berperan penting dalam diagnosis klinis sepsis karena dapat membedakan sepsis dari penyebab noninfectious systemic inflammatory respone syndrome (SIRS). ${ }^{4}$ Prokalsitonin merupakan parameter baru yang ditambahakan sebagai biomarker sepsis dalam beberapa tahun terakhir. Pada sepsis dan infeksi bakterialis prokalsitonin diketahui mengalami peningkatan lebih awal dibandingkan $c$ reaktive protein (CRP) atau sel darah putih. Kadar prokalsitonin akan meningkat ketika jumlah sitokin proinflamasi dalam tubuh seperti interleukin-6 (IL-6) dan tumor necrosis factor- $\alpha$ (TNF- $\alpha)$ meningkat. ${ }^{5}$

Pada penderita sepsis, selain terjadi peningkatan kadar prokalsitonin juga terjadi perubahan jumlah sel darah putih. $^{6}$ Salah satu sel darah putih yang mengalami perubahan adalah eosinofil. Penurunan jumlah eosinofil atau eosinopenia telah lama diketahui sebagai respons inflamasi tipe akut. $^{7}$ Pemeriksaan eosinofil menjadi salah satu penanda diagnosis sepsis yang banyak digunakan. Akan tetapi, pemeriksaan kadar prokalsitonin lebih dianjurkan karena memiliki sensitivitas yang tinggi. Akan tetapi, pada beberapa laboratorium terdapat keterbatasan dalam penentuan kadar prokalsitonin. Penelitian ini bertujuan untuk 
mengetahui hubungan antara kadar prokalsitonin dan jumlah eosinofil sebagai biomarker diagnosis sepsis.

\section{METODE}

Penelitian ini merupakan penelitian deskriptif observasional analitik dan dilaksanakan di RSUD Dr. Saiful Anwar Malang periode Januari-Desember 2016. Jumlah subjek penelitian ini sebanyak 74 pasien dengan kriteria inklusi di antaranya, semua pasien yang yang memenuhi 2 atau lebih kriteria SIRS menurut Delinger dkk.(2013) disertai denagn adanya infeksi sudah terbukti/diketahui (Tabel 1), pasien dirawat di ruang ICU, dan berusia $\geq 18$ tahun. Kriteria ekslusi penelitian ini yaitu pasien berusia $<18$ tahun, didiagnosis kanker darah, pasien dengan kondisi syok akibat pendarahan, pasien terinfeksi HIV, pasien dengan infeksi parasit, dan pasien dengan asthma bronchiale aktif. Data kadar prokalsitonin diperoleh dari data rekam medis pasien. Data jumlah eosinofil diperoleh dari data laboratorium pasien ICU RSUD Dr. Saiful Anwar Malang. Kadar prokalsitonin normal berkisar $<0.5 \mathrm{ng} / \mathrm{ml}$. Jumlah eosinofil normal antara $50-500 \mathrm{sel} / \mathrm{mm}^{3}$. Data diperoleh dianalisis dengan SPSS 16 dengan nilai $\mathrm{p}<0.05$. Uji statistik yang dilakukan diantaranya uji normalitas, uji homogenitas, dan uji korelasi Spearman.

Tabel 1. Kriteria SIRS menurut Delinger dkk. (2013)

\begin{tabular}{ll}
\hline & Kriteria \\
\hline & Temperatur tubuh $>38{ }^{\circ} \mathrm{C}$ atau $<36{ }^{\circ} \mathrm{C}$ \\
& Frekuensi jantung $>90$ kali permenit \\
SIRS & Frekuensi respirasi $>20$ kali permenit atau $\mathrm{PaCO}_{2}$ \\
& $<32 \mathrm{mmHg}$ \\
& Hitung sel darah putih $>12.000 \mathrm{sel} / \mathrm{mm}^{3}$ atau \\
Sepsis & $>10 \%$ bentuk immatur \\
& SIRS dengan adanya infeksi (diduga atau sudah \\
Sepsis Berat & terbukti) \\
Syok septik & Sepsis dengan disfungsi organ \\
& Sepsis dengan hipotensi walaupun sudah \\
& diberikan resusitasi yang adekuat \\
\hline
\end{tabular}

\section{HASIL}

Subjek penelitian ini adalah 74 pasien yang memenuhi kriteria inklusi. Karakteristik subjek penelitian tercantum dalam Tabel 2. Pada penelitian ini, jumlah subjek laki-laki sebanyak 25 individu (33.8\%), sedangkan subjek wanita sebanyak 49 individu $(66.2 \%)$. Umur subjek terdiri dari empat kelompok yaitu 18-30 tahun sebanyak 20 individu, 31-45 tahun sebanyak 20 individu, 46-60 tahun sebanyak 17 individu, dan >60 tahun sebanyak 17 individu.

Tabel 2. Karakteristik subjek penelitian

\begin{tabular}{lcc}
\hline & Karakteristik & Jumlah $(\%)$ \\
\hline Jenis kelamin & Laki-laki & $25(33.8)$ \\
Umur & Perempuan & $49(66.2)$ \\
& $18-30$ & $20(27)$ \\
& $31-45$ & $20(27)$ \\
& $46-60$ & $17(23)$ \\
& $>60$ & $17(23)$ \\
\hline
\end{tabular}


Pada penelitian ini, dilakukan uji korelasi Sprearman untuk menentukan hubungan antara kadar prokalsitonin dan jumlah eosinofil. Berdasarkan hasil penelitian, kadar prokalsitonin berbanding terbalik dengan jumlah eosinofil dalam darah (Gambar 1). Berdasarkan uji korelasi Spearman, terdapat korelasi yang kuat antara jumlah eosinofil dan kadar prokalsitonin pada pasien sepsis dengan koefisien korelasi sebesar -0,610. Hal ini berarti terdapat korelasi yang kuat antara kadar prokalsitonin dan jumlah eosinofil. Akan tetapi, korelasi yang diberikan bersifat negatif.

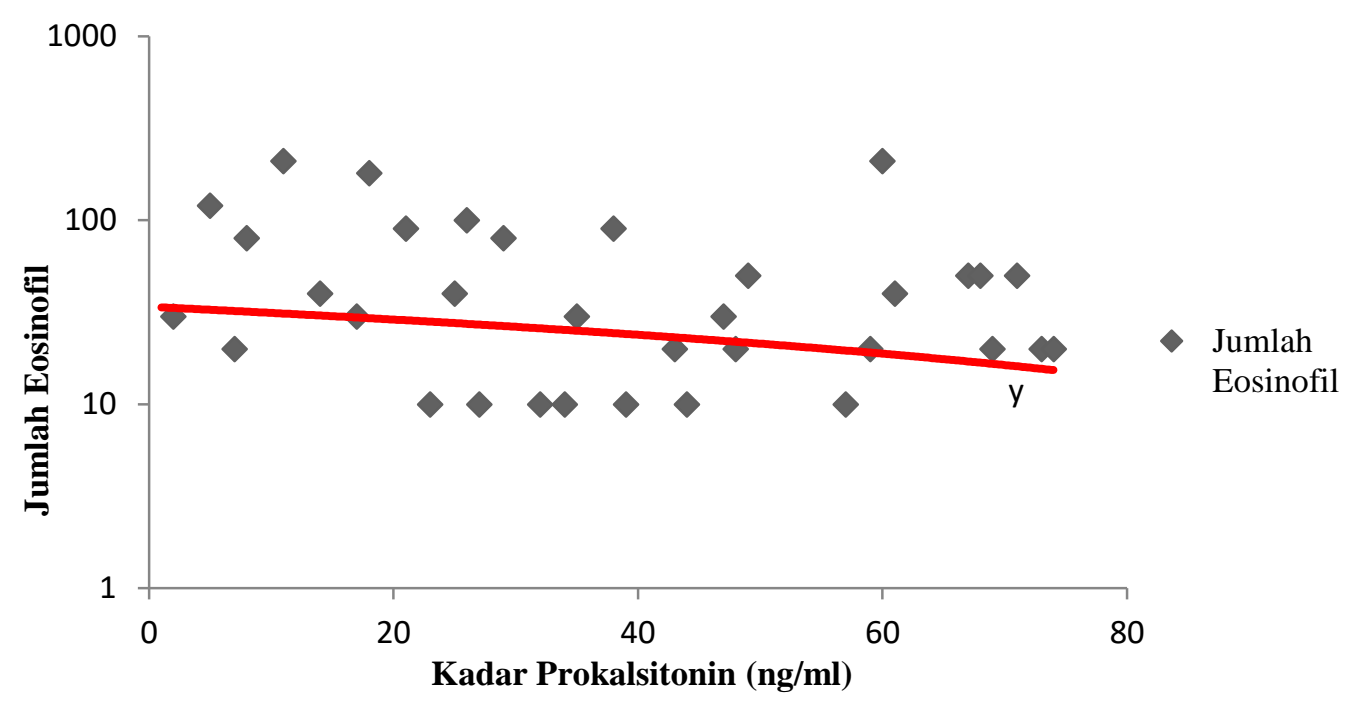

Gambar 1. Korelasi antara kadar prokalsitonin dan jumlah eosinofil

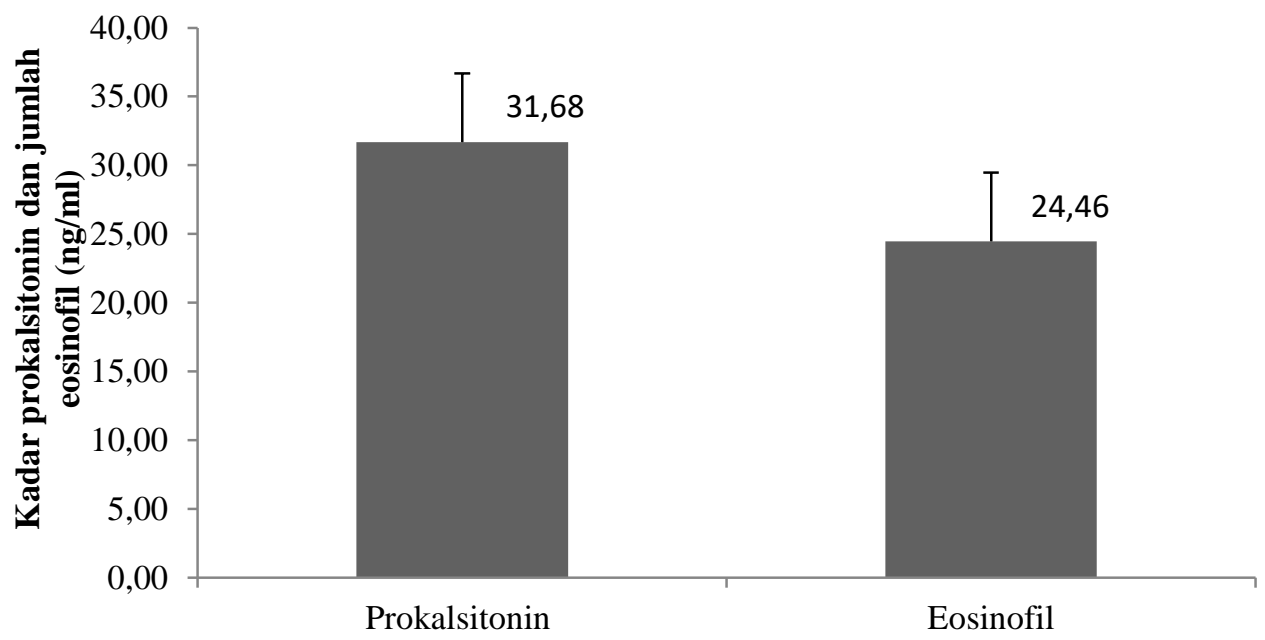

Gambar 2. Kadar prokalsitonin dan jumlah eosinofil pada subjek penelitian 


\section{PEMBAHASAN}

Subjek penelitian ini adalah 74 pasien sepsis yang terdiri dari $25(33,8 \%)$ individu laki-laki dan $49 \quad(66,2 \%)$ individu perempuan. Kelompok umur subjek terdiri dari empat kelompok yaitu 18-30 tahun sebanyak 20 individu, 31-45 tahun sebanyak 20 individu, 46-60 tahun sebanyak 17 individu, dan >60 tahun sebanyak 17 individu. Pada penelitian yang dilaksanakan oleh Barnato dkk. ${ }^{9}$ dengan melibatkan 71,1 juta pasien menunjukkan bahwa sepsis lebih banyak diderita oleh wanita dengan persentase $54,4 \%$ dengan rata-rata umur pasien sepsis adalah 36,1 tahun.

Pada penelitian ini, terdapat peningkatan kadar prokalsitonin lebih dari $2 \mathrm{ng} / \mathrm{ml}$ pada 64 pasien. Jumlah eosinofil berbanding terbalik dengan kadar prokalsitonin. Sebanyak 61 pasien mengalami penurunan jumlah eosinofil menjadi kurang dari 50 sel $(\mathrm{p}<0,05)$. Peningkatan kadar prokalsitonin menjadi $2 \mathrm{ng} / \mathrm{ml}-10 \mathrm{ng} / \mathrm{ml}$ bahkan telah menunjukkan adanya severe sepsis hingga septic shock. ${ }^{10}$ Peningkatan kadar prokalsitonin merupakan salah satu bentuk respons imun terhadap adanya infeksi. Infeksi mikroba dapat meningkatkan ekspresi gen CALC-1 yang menyebabkan lepasnya prokalsitonin dari seluruh sel parenkim dan sel-sel yang terdiferensiasi di hati maupun sel mononuclear. ${ }^{11}$ Pelepasan prokalsitonin dapat melalui induksi oleh toksin mikroba (endotoksin) dan induksi oleh sitokin pro-inflamasi. ${ }^{12}$ Penelitian oleh Hyuck $^{13}$ mengemukakan jika prokalsitonin merupakan biomarker yang menjanjikan untuk infeksi bakterialis dibandingkan untuk infeksi virus atau infeksi yang tidak spesifik. Hal ini karena endotoksin menginduksi CT-mRNA yang merangsang pembentukan prokalsitonin. Infeksi akibat virus tidak dapat menginduksi sekresi prokalsitonin karena interferon gamma virus menghambat translasi mRNA prokalsitonin. ${ }^{14}$

Pada subjek penelitian yang mederita sepsis, rata-rata kadar prokalsitonin mengalami peningkatan dari ambang normal. Kadar prokalsitonin subjek mencapai 31,68 ng/ml dari ambang normal yang hanya sebanyak 0,5 ng/ml. ${ }^{15}$ Hal yang berkebalikan terjadi pada jumlah eosinofil. Pasien sepsis memiliki rata-rata eosinofil sebanyak $24,46 \mathrm{sel} / \mathrm{mm}^{3}$ atau setengah kali lebih rendah dari ambang normal eosinofil. Jumlah normal eosinofil sebanyak 1-3\% dari total leukosit perifer atau antara 50$500 \mathrm{sel} / \mathrm{mm}$. $^{3,16,17}$

Penelitian ini menunjukkan jika sebagian besar pasien sepsis mengalami penurunan jumlah eosinofil atau disebut eosinopenia. Penurunan jumlah eosinofil merupakan salah satu bentuk respons imun akibat adanya infeksi. ${ }^{7}$ Eosinofil merupakan komponen imunitas innate yang berperan dalam respons anti bakteri. Eosinofil dapat memproduksi sitokin dan growth factor yang berkaitan dengan fungsi imunomodulasi. ${ }^{18}$ Penurunan jumlah eosinofil pada penderita sepsis terjadi akibat sekuestrasi cepat eosinofil disirkulasi darah perifer. Proses sekuestrasi eosinofil berhubungan dengan migrasi eosinofil ke daerah yang mengalami inflamasi. ${ }^{16}$

Hasil penelitian ini mendukung hasil penelitian yang dilaksanakan oleh Usama $\mathrm{dkk}^{19}$ yang menyatakan bahwa kadar prokalsitonin mengalami peningkatan ketika terjadi infeksi bakteri. Kadar prokalsitonin kemudian menurun secara cepat setelah mendapat treatment. Kecepatan prokalsitonin untuk merespons adanya infeksi bakteri yang lebih cepat dibandingkan biomarker lain seperti eosinofil, $c$ - 
reactive protein (CRP) dan leukosit lainnya menyebabkan prokalsitonin direkomendasikan untuk menjadi biomarker sepsis. Pada penelitian ini, kadar prokalsitonin pada pasien sepsis rata-rata mengalami peningkatan. Hasil penelitian ini juga mendukung penelitian yang dilaksanakan oleh Gupta dkk. ${ }^{20}$ yang menyatakan bahwa kadar prokalsitonin pada kultur sel yang diinduksi sepsis lebih tinggi dari kontrol. Namun masih perlu dilakukan penelitian lain untuk memastikan hasil studi invitro yang telah dilakukan. Penelitian ini dapat menjadi bukti penelitian in-vivo dan benar telah menunjukkan bahwa penderita sepsis memiliki kadar prokalsitonin yang tinggi.

Kadar prokalsitonin dan jumlah eosinofil memiliki korelasi yang kuat, namun bersifat negatif. Pada penelitian ini, jumlah eosinofil berbanding terbalik dengan kadar prokalsitonin. Pasien yang memiliki jumlah eosinofil rendah memiliki kadar prokalsitonin yang tinggi. Hal ini menunjukkan pasien dalam kondisi sepsis. Penggunaan prokalsitonin sebagai biomarker sepsis lebih akurat karena dapat menunjukkan jenis sepsis. Kadar prokalsitonin 0,05 $\mathrm{ng} / \mathrm{ml}-0,5 \mathrm{ng} / \mathrm{ml}$ menunjukkan adanya infeksi lokal, kadar prokalsitonin 0,5 ng/ml-2 ng/ml menunjukkan adanya sepsis, kadar prokalsitonin $2 \mathrm{ng} / \mathrm{ml}-10$ $\mathrm{ng} / \mathrm{ml}$ menunjukkan adanya severe septic, dan kadar prokalsitonin $>10$ $\mathrm{ng} / \mathrm{ml}$ menunjukkan adanya septic shock. ${ }^{10}$ Kombinasi prokalsitonin dan eosinofil sebagai biomarker dapat meningkatkan keakuratan diagnosa sepsis. Adanya hubungan yang kuat antara kedua biomarker menunjukkan bahwa eosinofil dapat digunakan sebagai biomarker sepsis oleh fasilitas kesehatan yang belum memiliki pemeriksaan laboratorium kadar prokalsitonin.
Kekurangan penelitian ini yaitu masih digunakannya SIRS dalam penegakan diaknosa. Penelitian selanjutnya dapat dilaksanakan dengan menggunakan kriteria Sequential Organ Failure Assessment (SOFA) untuk penegakkan diagnosis sepsis.

\section{KESIMPULAN}

Penderita sepsis memiliki kadar prokalsitonin yang berbanding terbalik dengan jumlah eosinofil. Jumlah eosinofil dan prokalsitonin dapat digunakan untuk memprediksi kondisi pasien sepsis. Eosinofil berpotensi menjadi alternatif biomarker diagnosis sepsis pada fasilitas kesehatan yang tidak memiliki fasilitas pemeriksaan kadar prokalsitonin.

\section{DAFTAR PUSTAKA}

1. Tannehill D. Treating Severe Sepsis \& Septic Shock in 2012. J Blood Disord Transfus. 2013;01:2-7

2. Sodik DC, Pradipta IS, Lestari K. Manajemen Terapi Sepsis. Students e-Journal. 2012; 1(1): 38

3. Faix JD. Critical Reviews in Clinical Laboratory Sciences Biomarkers of sepsis Biomarkers of sepsis*. Crit Rev Clin Lab Sci. 2013; 50 (501): 23-36

4. Arkader R, Troster EJ, Lopes MR, et al. Procalcitonin does discriminate between sepsis and systemic inflammatory response syndrome. Arch Dis Child. 2006; 91 (2): 117120

5. Ljungström L, Pernestig AK, Jacobsson G, Andersson R, Usener B, Tilevik D. Diagnostic accuracy of procalcitonin, neutrophillymphocyte count ratio, C-reactive protein, and lactate in patients with suspected bacterial sepsis. PLoS One. 2017; 12 (7): 1-17

6. Davido B, Makhloufi S, Matt M, et al. Changes in eosinophil count 
during bacterial infection: revisiting an old marker to assess the efficacy of antimicrobial therapy. Int J Infect Dis. 2017; 61: 62-66

7. Wen T, Rothenberg E. The Regulatory Function of Eosinophils. Microbiol Spectr. 2016; 4 (5): 1-19

8. Dellinger RP, Levy MM, Rhodes A, et al. Campanha de sobrevivência à sepse: Diretrizes internacionais para tratamento de sepse grave e choque séptico: 2012. Crit Care Med. 2013; 41 (2): 580-637

9. Barnato AE, Alexander SL, LindeZwirble WT, Angus DC. Racial variation in the incidence, care, and outcomes of severe sepsis: Analysis of population, patient, and hospital characteristics. Am J Respir Crit Care Med. 2008; 177 (3): 279-284

10. Vijayan AL, Ravindran S, Saikant R, Lakshmi S, Kartik R, Manoj G. Procalcitonin: A promising diagnostic marker for sepsis and antibiotic therapy. J Intensive Care. 2017; 5 (1): 1-7

11. Samsudin I, Vasikaran SD. Clinical utility and measurement of procalcitonin. Clin Biochem Rev. 2017; 38 (2): 59-68

12. Nakamura M, Kono R, Nomura S, Utsunomiya H. Procalcitonin : Mysterious Protein in Sepsis. J Basic Clin Med. 2013; 2 (15): 3-7

13. Lee H. Procalcitonin as a biomarker of infectious diseases. Korean J Intern Med. 2013; 28 (3): 285-291
14. Schuetz P, Albrich W, Mueller B. Procalcitonin for diagnosis of infection and guide to antibiotic decisions: Past, present and future. BMC Med. 2011; 9 (1): 107

15. Cleland D, Eranki A. Procalcitonin. https://www.ncbi.nlm.nih.gov/book s/NBK539794/. Diakses pada 15 Agustus 2019

16. Abidi K, Khoudri I, Belayachi J, et al. Eosinopenia is a reliable marker of sepsis on admission to medical intensive care units. Crit Care. 2008; 12 (2): $1-10$

17. Uhm TG, Kim BS, Chung Y. Eosinophil development, regulation of eosinophil-specific genes, and role of eosinophils in the pathogenesis of asthma. Allergy, Asthma Immunol Res. 2012; 4 (2): 68-79

18. Davoine F, Lacy P. Eosinophil cytokines, chemokines, and growth factors: Emerging roles in immunity. Front Immunol. 2014; 5: $1-17$

19. Alkholi UM, Abd Al-Monem N, Abd El-Azim AA, Sultan MH. Serum procalcitonin in viral and bacterial meningitis. J Glob Infect Dis. 2011; 3 (1): 14-18

20. Gupta S, Jaswani P, Sharma RK, et al. Procalcitonin as a diagnostic biomarker of sepsis: A tertiary care centre experience. J Infect Public Health. 2019; 12 (3): 323-329 